\title{
Aplicação da análise visual em duas unidades de paisagem da bacia hidrográfica do rio Pitangui, PR, mediante processamentos digitais
}

\author{
Aplicación del análisis visual en dos unidades de paisaje de la \\ cuenca del río Pitangui, PR, a través de procesamiento digital
}

\section{Application of visual analysis in two landscape units of river basin Pitangui, PR, through digital processing}

\author{
Carla Eva Prichoa \\ cprichoa@yahoo.com.br \\ Universidad Autónoma de Madrid \\ Selma Regina Aranha Ribeiro \\ selmar.aranha@gmail.com \\ Universidade Estadual de Ponta Grossa \\ Pedro Molina Holgado \\ pedro.molina@uam.es \\ Universidad Autónoma de Madrid
}

\begin{abstract}
Resumo: Atualmente, muitos são os métodos para análise e caracterização das paisagens; porém, de maneira maciça, as técnicas de Sistemas de Informação Geográfica (SIG) e Sensoriamento Remoto (SR) apresentam impactos na produção e disponibilização de produtos cartográficos, minimizando custos e otimizando a validação a campo. Neste contexto, a presente pesquisa foi desenvolvida utilizando-se a classificação qualitativa, ou seja, visual, voltada à caracterização e ao reconhecimento de padrões físicos, bem como de ocupação de duas unidades de paisagem pertencentes à bacia hidrográfica do rio Pitangui, que abrange os municípios de Castro, Carambeí e Ponta Grossa, localizados no centro-leste do estado do Paraná. O estudo envolveu a utilização de imagem de satélite Landsat 5 TM, que forneceu visão global, particular das unidades e os valores de refletância dos alvos nelas contidos. Os dados referentes às bandas espectrais e do relevo foram integrados, relacionados e espacializados em ambiente SIG, extraindo variáveis de relevo e de hidrografia a fim de se realizar reconhecimento visual e topográfico prévio das unidades. Como resultado, notase que ambas as unidades de paisagem apresentam heterogeneidade nos padrões tanto físicos quanto de uso e ocupação. A primeira unidade possui características topográficas em algumas áreas, as quais impedem o manejo, notadas principalmente a sudeste da área. A segunda unidade, apesar de possuir relevo que favorece mais o uso e ocupação, possui porções mais elevadas e declivosas, observadas principalmente ao norte, nordeste e sudeste da área.
\end{abstract}

Palavras-chave: Unidades de paisagem. Sensoriamento Remoto. Sistemas de Informação Geográfica. Processamento de Imagens Digitais. Rio Pitangui. 
Resumen: Actualmente, existen muchos métodos para el análisis y la caracterización de los paisajes, pero a gran medida, las técnicas de Sistemas de Información Geográfica (SIG) y Teledetección (RS) presentan impactos sobre la producción y disponibilidad de productos cartográficos, minimizando costos y optimizando la validación en terreno. En este contexto, esta investigación se llevó a cabo utilizando la clasificación cualitativa, es decir, visual, dirigida a la caracterización y reconocimiento de los patrones físicos, así como el uso y ocupación de dos unidades de paisaje que pertenecen a la cuenca del río Pitangui, que abarca los municipios de Castro, Carambeí y Ponta Grossa, en el centroeste del estado de Paraná. El estudio incluyó el uso de imágenes de satélite Landsat 5 TM, que proporcionó visión global, particular de las unidades y los valores de reflectancia de los albos contenidos en el mismo. Los datos relativos a las bandas espectrales y del relieve fueron integrados, vinculados y espacializados en SIG, extrayendo variables de relieve e hidrografía con el fin de realizar el reconocimiento visual y topográficas de las unidades. Como resultado, se observa que las dos unidades de paisaje presentan patrones de heterogeneidad física y de uso y ocupación. La primera unidad tiene características topográficas en algunas áreas que impiden la gestión, sobretodo en la zona sureste. La segunda unidad, a pesar de poseer relieve más favorable al uso y la ocupación, tiene porciones más elevadas y de mayor pendiente, principalmente, en el norte, noreste y sureste de la zona.

Palabras-clave: Unidades de paisaje. Teledetección. Sistemas de Información Geográfica. Procesamiento Digital de Imágenes. Río Pitangui.

\begin{abstract}
Currently, there are many methods for analysis and characterization of landscapes, although, so massive, the techniques of GIS (Geographic Information Systems) and RS (Remote Sensing) have impacts on the production and availability of cartographic products, minimizing costs and optimizing the validation field. In this context, the present research was conducted using qualitative classification, i.e, visual, focused on the characterization and recognition of physical standards as well as occupancy of two landscape units belonging to the river basin Pitangui, which covers the municipalities of Castro, Ponta Grossa and Carambeí, all regions are located in the center-east of the state of Paraná. The study involved Landsat 5 TM image, which provide overall and particular vision of units and values reflectance of the targets contained therein. Data regarding the spectral bands and relief were integrated and spatially related to GIS, extracting variable relief and hydrography in order to perform visual recognition and topographic prior units. As a result, we noticed that the two units Landscape presented heterogeneity in both physical and patterns of use and occupation. The first unit has topographical features in some areas which prevent management, noted mainly for Southeast area. The second unit, despite having raised more which favors the use and occupation, has more servings high and steep observed mainly in the north, northeast and southeast of the area.
\end{abstract}

Keywords: landscape units. Remote Sensing. Systems Geographic Information. Digital Image Processing. Pitangui River.

\title{
INTRODUÇÃO
}

A Análise Visual é um método utilizado para reconhecer previamente, numa determinada paisagem, as características homogêneas/heterogêneas de uso e ocupação, bem como de padrões físicos dominantes. 
A interpretação da estrutura espacial das paisagens está ligada à descrição do locus vivenciado pela sociedade. Ou seja, dependendo do ângulo analisado, pode-se observar o conjunto de formas e novos padrões, caracterizados como mosaicos naturais, responsáveis pelas feições individuais de cada região do planeta.

Nesta pesquisa o termo "paisagem" é contextualizado sob experiências de autores como: Forman, (1995); Forman e Godron, (1986); Turner et al (2001); Gardner e O'Neill, 2001; Burel e Baudry, (2002), os quais percebem suas estruturas e padrões espaciais como manifestações espaciais/temporais de processos que ocorrem em diferentes escalas, influenciando o desenvolvimento de novos padrões e/ou estruturas paisagísticas, influenciadas, sobretudo, pelos elementos dominantes do espaço.

A análise visual de uma paisagem e/ou de agentes formadores da paisagem pode ser executada qualitativamente, à medida que se observam e se identificam as feições morfológicas do terreno, utilizando para isso os elementos de interpretação que são encontrados na imagem ou cena. E isso não se restringe apenas às propriedades espectrais armazenadas sob forma de valores digitais em cada pixel. Podem ser explorados os aspectos ligados à textura e à forma dos objetos, bem como a associação espacial entre os objetos que compõem a cena (CENTENO, 2003).

A existência de grandes unidades de paisagem é manifestada na sua fisionomia, porém, as unidades menores que a formam podem ser individualizadas a partir de análises das inter-relações dos elementos do meio (MOLINA, 1992).

A coleta, o tratamento, a análise e a disponibilização de informações espaciais associadas a mapas digitais georreferenciados são, hoje, realizados pela técnica Sistemas de Informação Geográfica, o SIG, e têm se constituído importante processo para a administração ambiental, fornecendo diretrizes que subsidiam a adoção de medidas, principalmente preventivas, além das corretivas, baseadas no conhecimento das potencialidades e das fragilidades do ambiente (BURROUGH, 1992).

O objetivo principal do SIG é servir de instrumento a todas as áreas de conhecimento que utilizem imagens e mapas, por meio da integração de informações de diferentes origens referentes a uma região em uma única base de dados referenciada espacialmente (BURROUGH, 1986), e que garante resultados eficazes ao ser aplicado em estudos relacionados a unidades de paisagem.

No entanto, Lang e Blaschke (2009) sustentam que o desafio presente do SIG é que sua utilização não seja somente para documentar estatisticamente a situação atual, mas utilizar sua funcionalidade analítica e modeladora para fomentar gerenciamento pró-ativo, com visão e planejamento para o futuro de fatos ambientais por meio de métodos que utilizem geotecnologias da área de modelagem, técnica de cenários e de observação constante.

O emprego do SIG no reconhecimento de uma área dentro de uma bacia hidrográfica contribui com o manejo e o gerenciamento, pois a divisão da bacia hidrográfica em segmentos pode servir tanto como diretriz para a coleta de dados bem como na aplicabilidade dos resultados (PRICHOA, 2012).

Para dar suporte ao propósito dos autores supracitados, Novo (1989), Lillesand et al., (2007) propõem o Sensoriamento Remoto (SR) e o definem como uma técnica 
responsável pela aquisição de informação sobre um objeto a partir de medidas feitas por um sensor que não se encontra em contato físico direto com ele. As informações são derivadas da detecção e mensuração das modificações impostas sobre os campos de força eletromagnéticos, acústicos ou potenciais.

O uso de imagens de satélite em conjunto com o SIG possibilita a definição de áreas ambientais homogêneas ou de unidades de paisagem com características similares, convertendo-se em uma forma adequada tanto para a análise dos resultados quanto para o planejamento das unidades de paisagem (BORROUGH, 1986; CENTENO, 2004; JENSEN, 2000; NOVO, 1989; RIBEIRO, 2003).

Para garantir melhores resultados e/ou evidenciar feições ou objetos nas imagens digitais, conta-se com o Processamento de Imagens Digitais (PDI). O PDI pode ser entendido como o aprimoramento de informações pictóricas para interpretação humana, ou seja, formas de se melhorar a visualização de objetos (MARQUES FILHO; VIEIRA NETO, 1999, GONZALES, 2000).

Moreira (2005) utiliza-se da técnica de PDI para criar procedimentos computacionais para análise de dados coletados por sensores e ressalta duas razões fundamentais: agilizar as tarefas manuais realizadas durante a interpretação visual e possibilitar ao analista introduzir outras informações, e cruzá-las com os padrões espectrais presentes na imagem, podendo assim esses padrões tornarem-se facilmente identificáveis.

Nesta pesquisa, as imagens de SR compõem um conjunto de variáveis, uma vez que as bandas espectrais registram a interação do comprimento de ondas eletromagnéticas com os objetos da superfície terrestre, podendo apresentar um contexto da paisagem na forma sinóptica e panorâmica. Além disso, realiza também a classificação digital supervisionada, gerando o mapa de uso atual das unidades de paisagem.

Diante do exposto, o objetivo principal desta pesquisa visa à caracterização e ao reconhecimento de padrões homogêneos/heterogêneos de duas unidades de paisagem da bacia hidrográfica do rio Pitangui, PR, mediante um conjunto de variáveis físicas e de uso e ocupação, extraídas de técnicas de SIG e SR.

Para alcançar a proposta agregam-se especificidades como:

- Aplicação da classificação multiespectral pixel a pixel - Máxima Verossimilhança;

- Análise e caracterização visual do relevo e hidrografia, por meio de atributos dos agentes formadores da paisagem, extraídos do MDT e sub-bacias;

\section{MATERIAL E MÉTODOS}

Para a elaboração deste estudo recorreu-se aos seguintes arquivos digitais: Carta topográfica de Ponta Grossa - PR, SG 22-X-C-II/ 2 (2005), na escala 1:50.000, imagem orbital Sensor Landsat 5 TM (órbitas 221/222 e pontos 69/70 de 09/2010), com resolução espacial de 30 metros e 6 bandas espectrais, disponibilizada gratuitamente pelo sítio do INPE; curvas de nível com equidistância de 20 metros e ortoimagem oriunda do Sensor 
SPOT 5 (2005), com resolução espacial de 5 metros, ambas cedidas pelo Paranacidade (SEDU-PR). Os processamentos foram realizados nos software: ARCGIS 9.3 e ENVI 4.4.

As unidades de paisagem possuem aproximadamente $127,7 \mathrm{~km}^{2}$ cada uma e fazem parte da bacia hidrográfica do rio Pitangui, abrangendo um total de área de 927,3 km², localizada a centro-leste do estado do Paraná, entre as latitudes $25^{\circ} 46^{\prime} 40^{\prime \prime}$ e 2549'06" S,

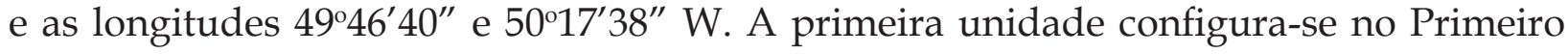
Planalto Paranaense (PPP), abrangendo os municípios de Ponta Grossa, Castro e Carambeí. A segunda unidade abrange parte da Escarpa Devoniana (ED) e o Segundo Planalto Paranaense (SPP), no município de Ponta Grossa (Figura 1).

A escolha das áreas é justificada pelo posicionamento das unidades, uma vez que o relevo do estado propõe um escalonamento sentido oeste, proporcionando morfologia peculiar e atribuindo destaque às formas heterogêneas encontradas.

Figura 01 - Localização das unidades de estudo

\section{Localização das Unidades de Paisagem de estudo}

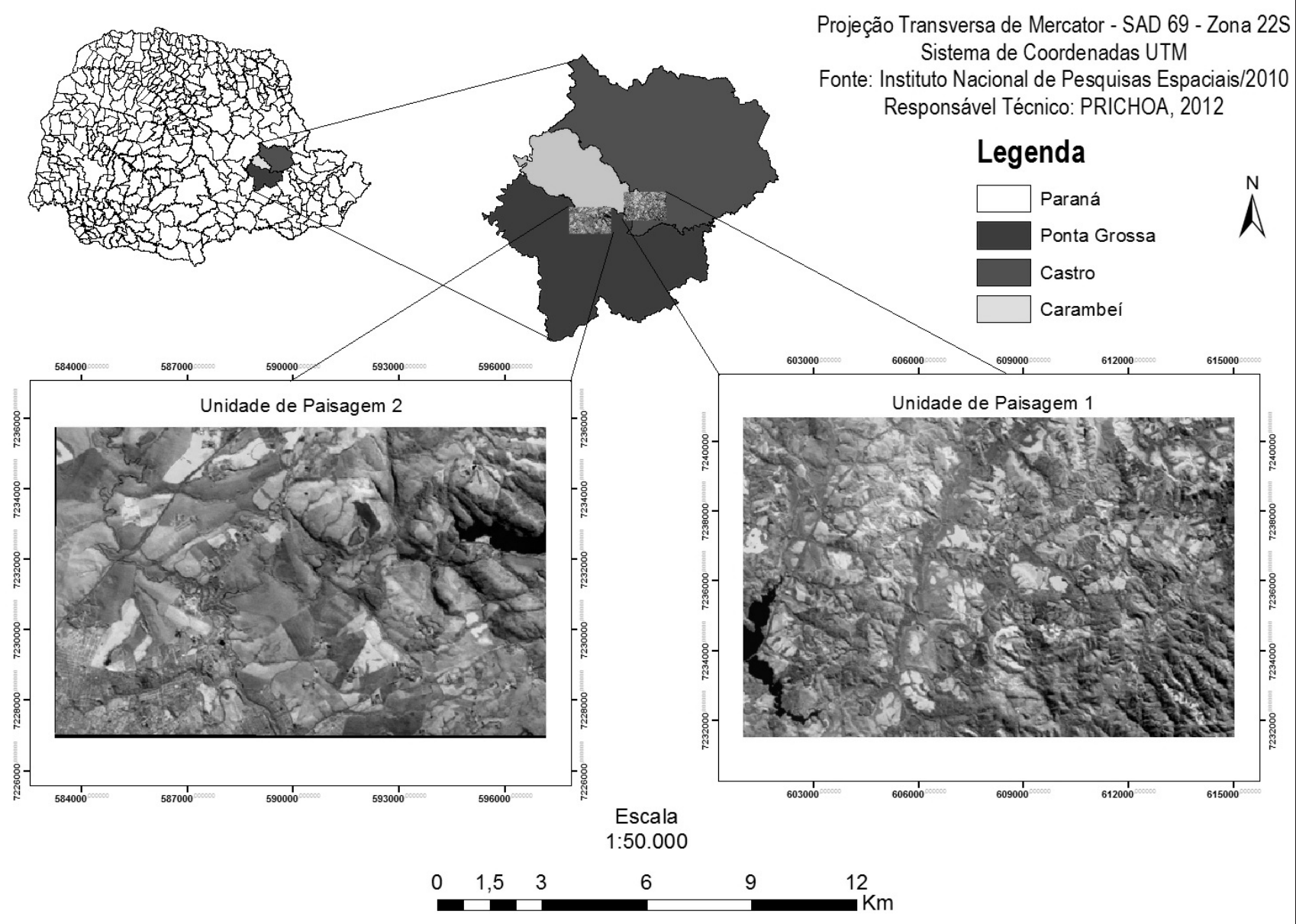

A região pertencente às unidades de estudo é composta por rochas sedimentares expostas pelo soerguimento e erosão do terreno (MELO et al., 2010), e representa a transição entre o Primeiro e o Segundo Planalto Paranaense. Caracteriza-se por uma região 
ecotonal, onde a vegetação do PPP, pertencente à zona fitoecológica Floresta Ombrófila Mista Montana, forma um mosaico climático-edáfico com a Estepe Gramíneo-Lenhosa do SPP (VELOSO et al., 1991).

Predominam Cambissolos Háplicos e Neossolos Litólicos formados sobre o arenito da Formação Furnas, o qual origina solos rasos, arenosos e bastante suscetíveis a processos erosivos (EMBRAPA, 2002). O clima na região da bacia do rio Pitangui é do tipo $\mathrm{Cfb}$ da classificação de Koeppen (MAACK, 2002). A temperatura média anual está entre $16^{\circ} \mathrm{C}$ e $22^{\circ} \mathrm{C}$ e os ventos têm predominância NE no verão e NW no inverno (CRUZ, 2007). A precipitação média anual situa-se entre $1.400 \mathrm{~mm}$ e $1.800 \mathrm{~mm}$, sendo o período mais seco de junho a agosto, e o período mais chuvoso de dezembro a fevereiro.

As etapas desenvolvidas nesta pesquisa podem ser observadas na Figura 2. Primeiramente realizou-se a correção geométrica da imagem orbital Landsat 5 TM pela transformação geométrica com 20 pontos de controle e notáveis, com o apoio da ortoimagem e da carta topográfica, obtendo-se o erro médio quadrático inferior à resolução espacial da imagem Landsat 5 TM $(30 \mathrm{~m})$. Em seguida, foram coletadas amostras de treinamento para elaboração da classificação supervisionada da imagem digital quanto ao uso e ocupação do solo, pelo algoritmo de Máxima Verossimilhança, no ENVI 4.4, comprovando-se as classes em campo. As curvas de nível foram utilizadas para o processamento do Modelo Digital do Terreno (MDT), usando-se o interpolador Inverse Distance Weighted (IDW) - Inverso de uma Distância Ponderada, no ArcGis 9.3. O MDT serviu de suporte para a composição de subprodutos como: declividade, aspecto, direção de escoamento e sub-bacias.

Figura 02 - Etapas da pesquisa

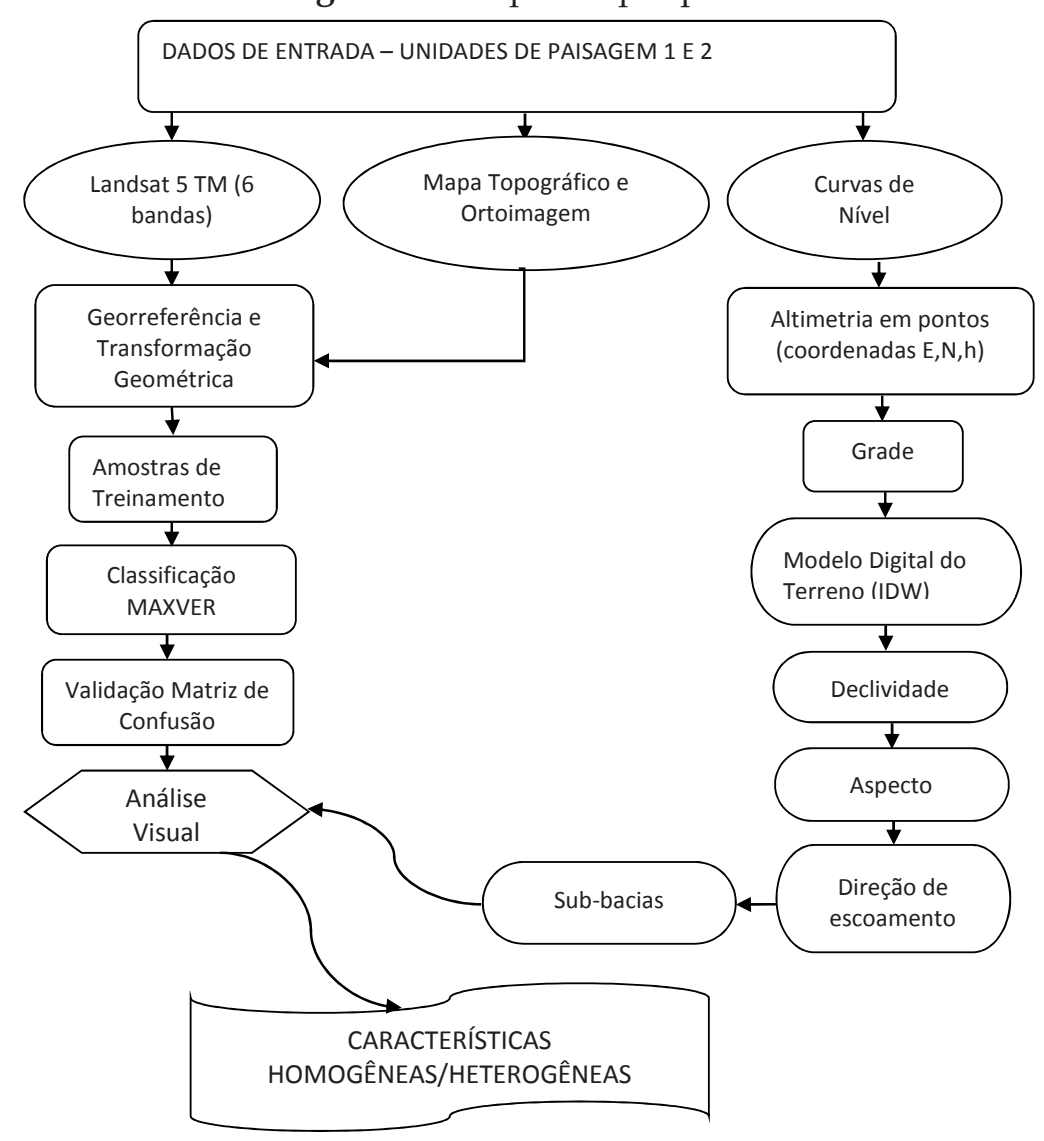


Pondera-se que, para se obter êxito neste tipo de análise, é indispensável a experiência do intérprete no que tange à utilização de técnicas de Sensoriamento Remoto e Sistemas de Informação Geográfica, bem como conhecimento prévio da área de estudo, ou seja, conhecimento de campo, para que possa realizar a interpretação adequada, identificando objetos, avaliando suas reais características e descrevendo-as de maneira legível.

\section{RESULTADOS E DISCUSSÃO}

A interpretação de imagens está associada às análises regionais, procedimento em que se avalia as mudanças ocorridas nos espaços em épocas distintas. Por isso, os elementos de interpretação de imagens são os princípios fundamentais que mais são usados rotineiramente ao se realizar uma fotointerpretação. Esses elementos incluem localização, tonalidade ou brilho e cor, tamanho, forma, textura, padrão, sombra, altura e profundidade, volume declividade, aspecto, situação e associação (JENSEN, 2009).

Para os resultados associados aos agentes formadores de paisagem usados nesta pesquisa buscou-se realizar comparação entre as unidades de estudo, a fim de conferir as características homogêneas/heterogêneas que mais se destacam na região. Salientase que as imagens representando as variáveis finais estão baseadas nas coordenadas da Figura 1.

Neste sentido, para análise relativa às altitudes da primeira unidade de paisagem (Figura 3) se destacam as porções sul e centro-leste, atingindo até 1.065 metros nos topos. Uma evidente diminuição na altitude é observada na extrema porção nordeste, exibindo índices de até 760 metros, isto é, menores que os índices notados nos vales dos rios Pitangui e Jotuba, que se apresentam próximos dos 900 metros. As porções restantes da área apresentam-se homogêneas, variando entre 930 e 995 metros, inclusive nas regiões centro-oeste e noroeste, onde se encontra o divisor topográfico dos rios supracitados.

Figura 3 - Imagem representando Modelo Digital do Terreno e hidrografia-primeira unidade de paisagem

Legenda

Classes

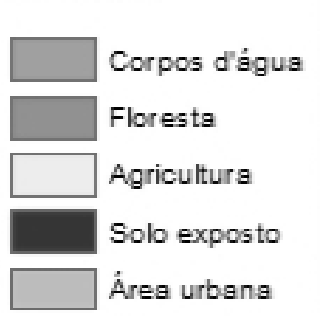

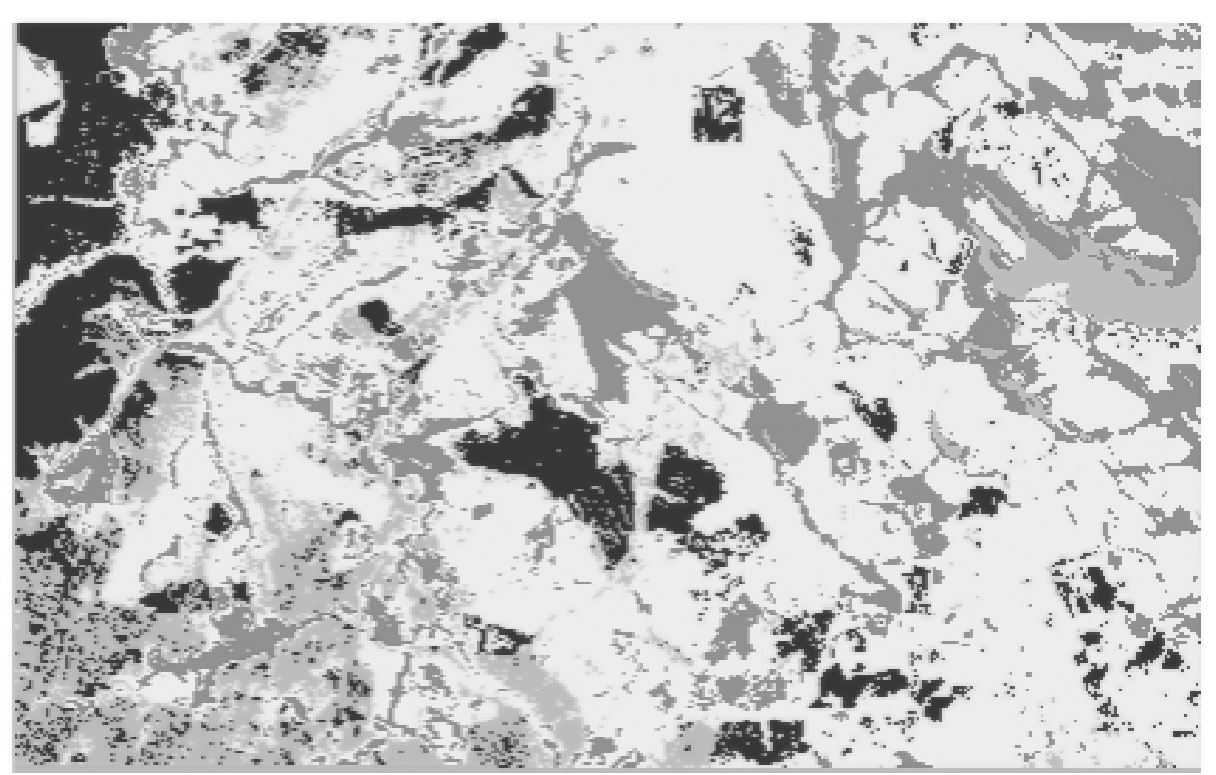


A segunda unidade de paisagem (Figura 4) é caracterizada por maiores áreas apresentando porções elevadas. Nota-se nas regiões norte, nordeste, leste e sudeste índices entre 1.000 e 1.090 metros de altitude. Essas elevações coincidem com as formas do relevo de transição do PPP para o SPP, confirmando-se, ao passo que se afasta para oeste, noroeste, sul e sudoeste, onde ocorrem diminuições significativas nas altitudes; principalmente no vale do rio Pitangui, que chega aos 820 metros na medida em que segue à sua foz.

Figura 4 - Imagem representando Modelo Digital do Terreno e hidrografia-segunda unidade de paisagem
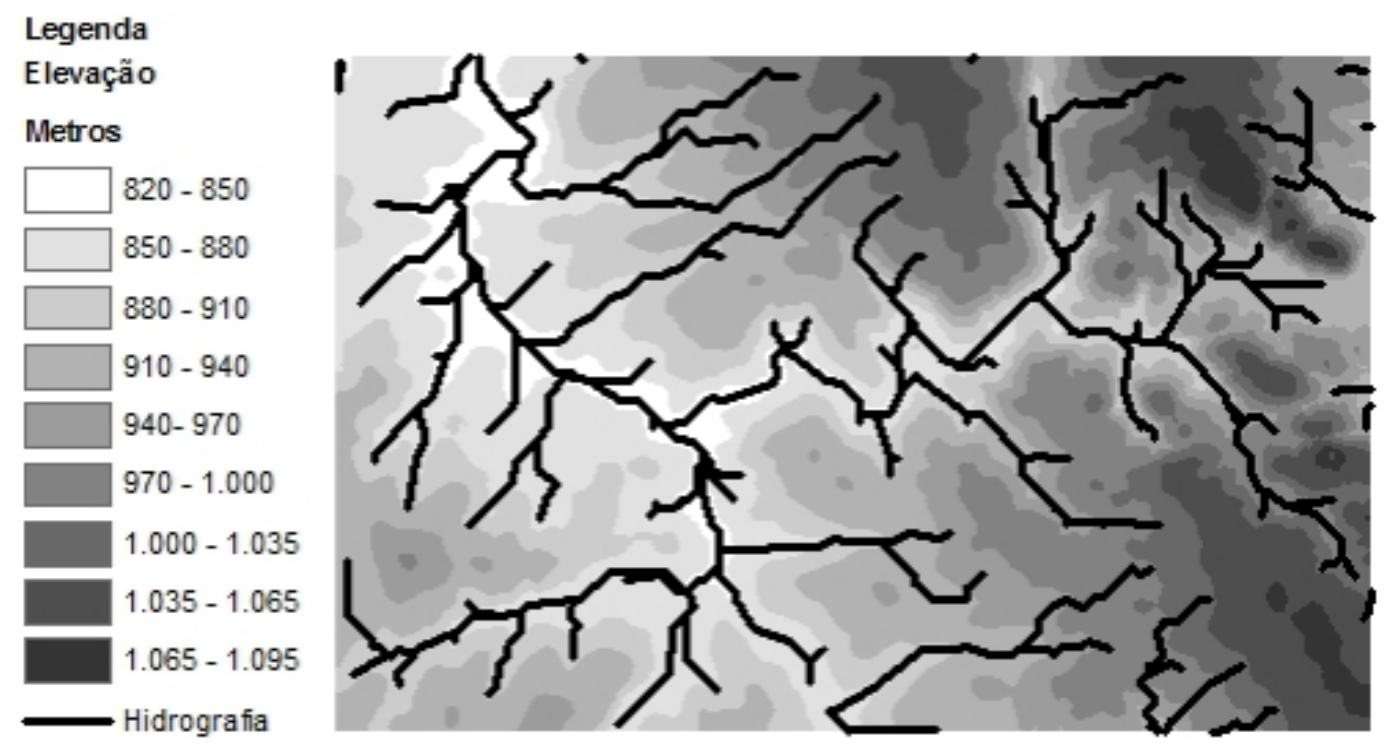

A visualização em perspectiva de unidades de estudo com base nos MDTs, em conjunto com a hidrografia de ambas as unidades de paisagem, possibilitou melhor identificação das regiões que, com características topográficas distintas, refletiram-se como principal suporte para a análise do perfil de uso da terra nos diferentes tipos de relevo. Estes produtos foram aplicados neste estudo, principalmente na geomorfologia, com a elaboração de imagens representando declividade, aspecto, concavidade e convexidade, análises de rede hidrográfica (delimitação automática de sub-bacias), ou seja, sob diferentes ângulos, para interpretação adequada de cada feição que caracteriza a paisagem.

Com relação à declividade, realizou-se a análise caracterizando as classes de declive de 0 a 40\%. A declividade acentua-se à medida que as isolinhas se juntam, conforme mostram os destaques nas imagens (Figuras 5 e 6).

A primeira unidade de paisagem (Figura 5) apresenta declividades superiores (20 a 40\%) numa porção da área que abrange as regiões sul, sudeste, leste-sudeste e nordeste-leste. São percebidos declives semelhantes em porções menos expressivas, como na região sudeste e próximo aos vales dos rios Pitangui e Jotuba (16 a 40\%). Essas áreas se configuram num relevo ondulado e/ou forte ondulado, que pode estar relacionado tanto com as maiores altitudes $(1.065 \mathrm{~m})$ nas regiões sul e centro-leste, como com as menores (780 m), encontradas no extremo sudeste da área. Classes de declive pouco expressivos (0 a $13 \%$ ) são observadas no restante da área, configurando-se num relevo plano ou suave ondulado. 
Figura 5 - Imagem representando declividade e hidrografia-primeira unidade de paisagem

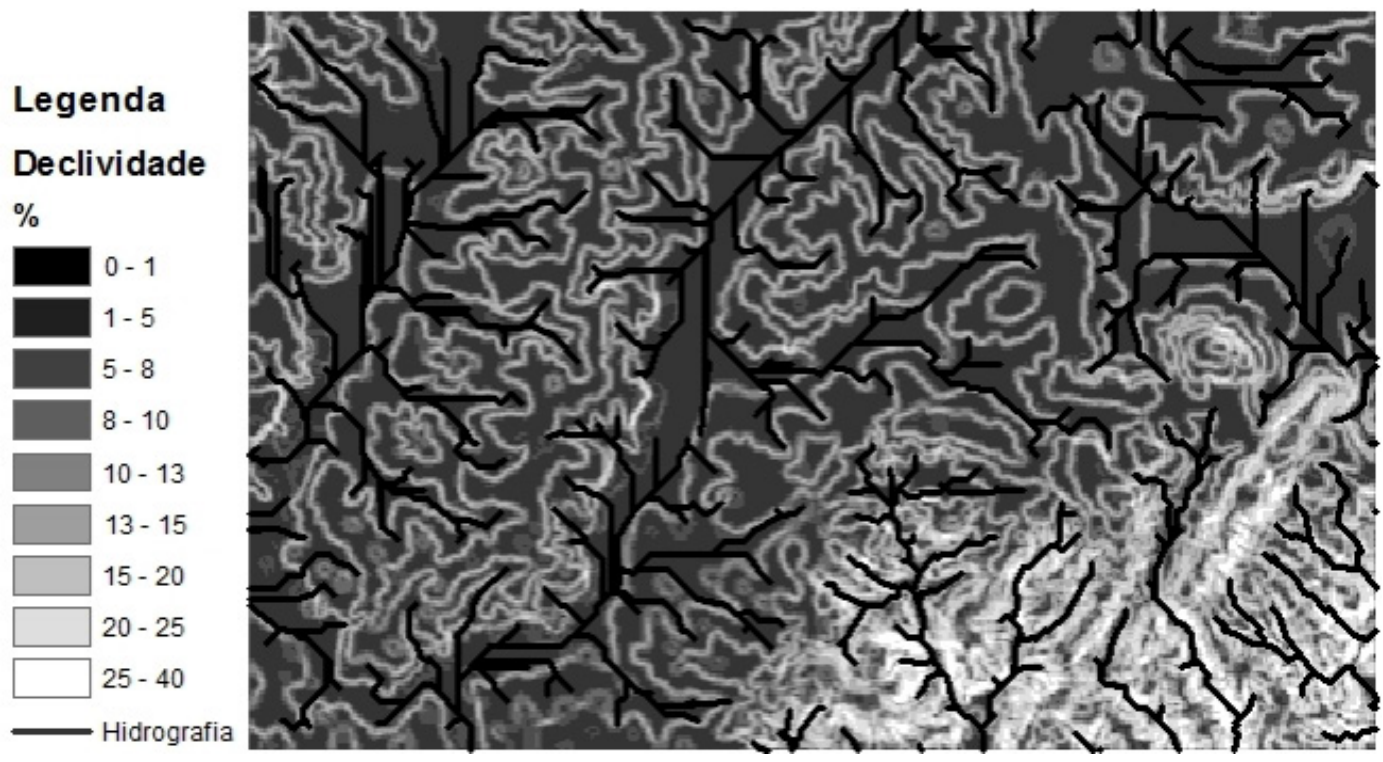

A classe superior de declividade (16 a 40\%) da segunda unidade de paisagem (Figura 6) encontra-se em porções que compreendem as regiões centro-leste e nordeste, configurando-se como forte onduladas com classes de elevação entre 940 e 970 metros. As classes de declive inferiores (16 a 20\%) encontram-se na região sudoeste, em altitudes entre 860 e 880 metros, principalmente sobre os canais fluviais que percorrem parte da área urbana até o rio Pitangui, como se pode observar na seta indicativa na porção sudoeste. Dessa forma, nesta área (Figura 6) observa-se que as declividades ocorrem, sobretudo, em elevações que variam de 860 a 970 metros, encontradas sob os vales dos afluentes do rio Pitangui, de ambas as margens a jusante, e outras vertentes provenientes da porção urbana (sudoeste). Esta característica diferencia-se da primeira unidade de paisagem, que apresenta declives acentuados tanto nas áreas mais elevadas (1.065 metros), como nas mais baixas (760 metros) da unidade.

Figura 6 - Imagem representando declividade e hidrografia-segunda unidade de paisagem

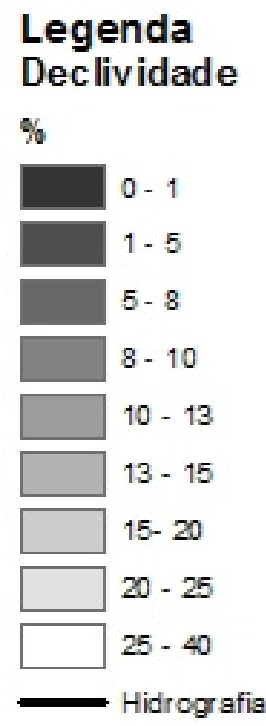

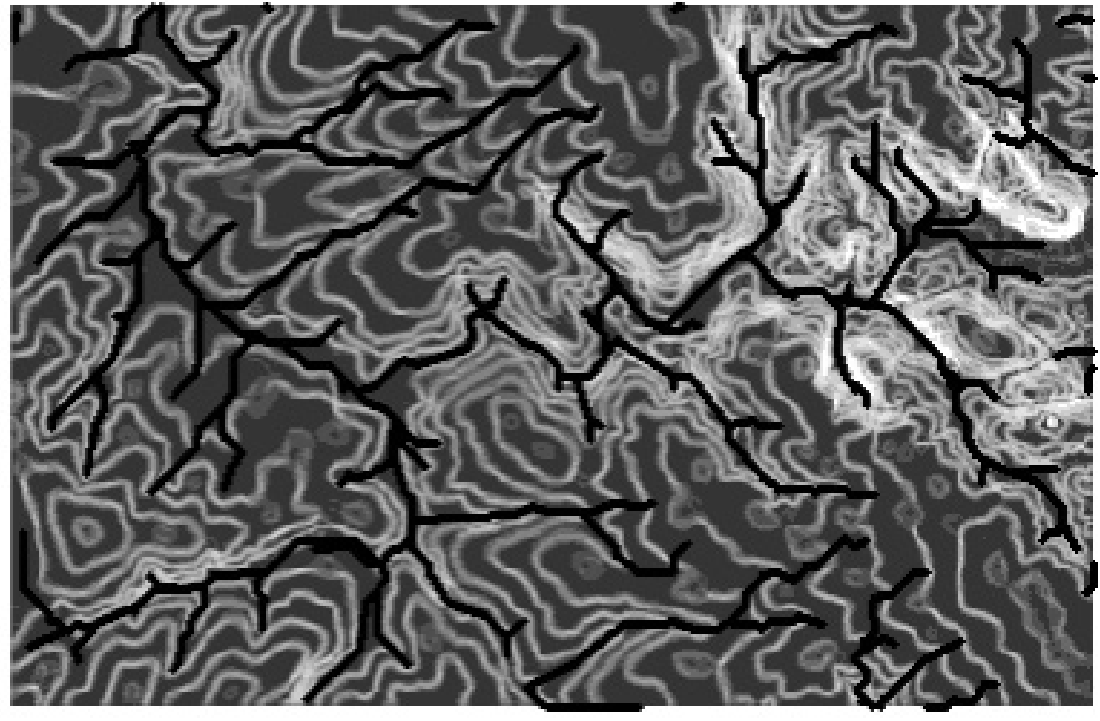


A interpretação visual das imagens em conjunto mostra que se trata de unidades de paisagem com padrões físicos heterogêneos. Comprova-se ao cruzar as classes de declives com os percentuais de altitude (Figuras 3 e 4), os quais mostraram que tanto nas porções elevadas como nas mais baixas da primeira unidade de paisagem (Figura 5) ocorreram declividades elevadas. Esse perfil influencia num modelamento topográfico fortemente ondulado, observado principalmente na porção sudeste da área. Tais características impulsionam para maior movimentação nessa região e menor aproveitamento, uma vez que o comprimento e a declividade das vertentes proporcionam o escoamento superficial e podem desencadear maior suscetibilidade litológica e erosão em alguns pontos. A segunda unidade de paisagem (Figura 6) contém maiores porções de área com índices superiores de elevação, porém, porções inferiores com índices de declividade elevada. A variável altitude, neste caso, pode não influenciar integralmente para o menor aproveitamento da área, podendo apresentar usos diversos em regiões elevadas, porém, topograficamente mais suaves, como nas porções centro-leste e nordeste. As porções da área ao sul, sudoeste, oeste e noroeste apresentam altitudes e classes de declive que influenciam visivelmente para o maior aproveitamento, principalmente por cultivares agrícolas.

Para a análise do aspecto (Figuras 7 e 8) foram adotadas dez classes, cada uma representada por uma cor e um sentido (ângulo em que está inserida). Os valores obtidos encontram-se entre -1 e $360^{\circ}$, sendo que o valor -1 representa as regiões planas identificadas pela cor cinza nas imagens. Esta variável está associada à luminosidade solar e também à direção preferencial do escoamento superficial. Como o relevo do Paraná, incluindo as unidades de paisagem de estudo, apresenta-se escalonado de leste para oeste do estado, a rede hidrográfica também segue esse padrão. Tal fator pode influenciar nas orientações das encostas das unidades de paisagem, porém, cruzando com as variáveis declividade e altimetria, o resultado apresenta ângulos com várias direções.

Figura 7: Imagem representando aspecto e hidrografia-primeira unidade de paisagem

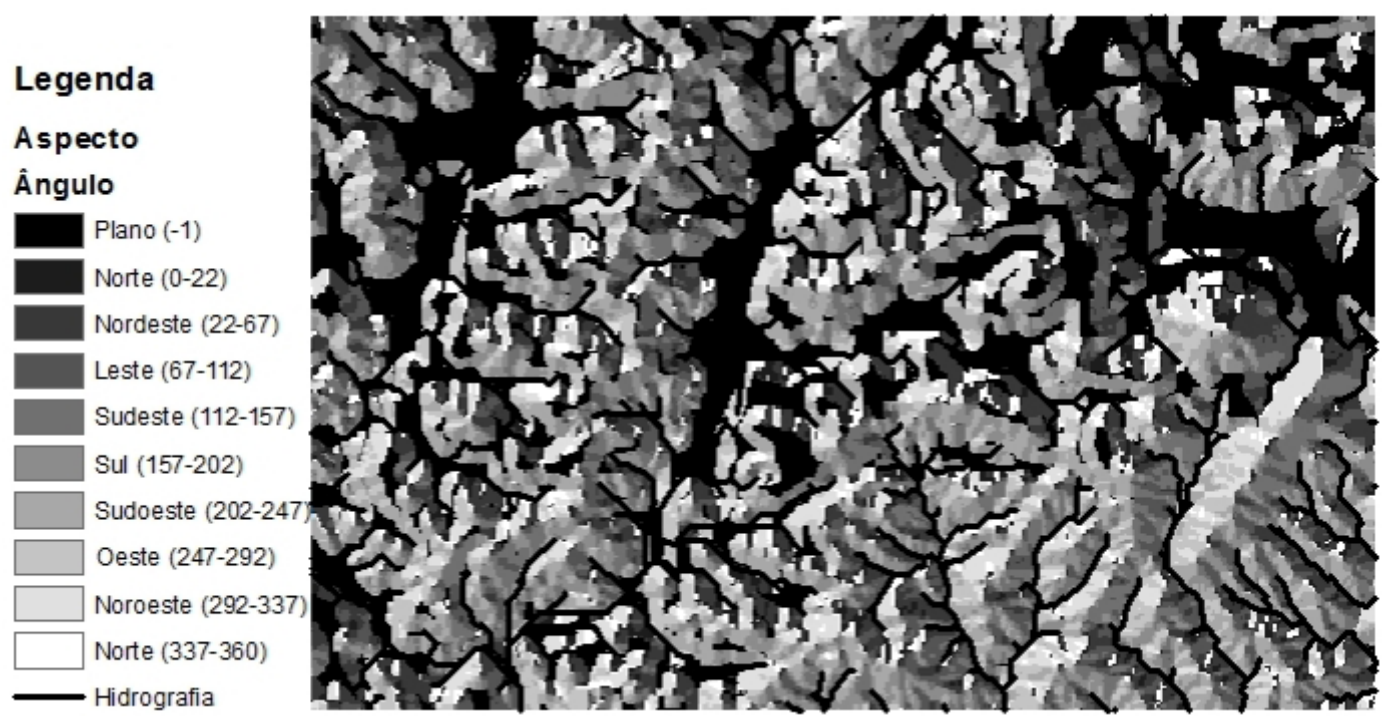


Para a primeira unidade de paisagem (Figura 7), as porções mais elevadas (1.000 a 1.065 metros) do terreno são observadas a leste-sudeste, (círculo), prevalecendo ângulos voltados para oeste e sudoeste. Em regiões da área onde predominam declividades superiores, como próximo aos vales dos rios, sobretudo do rio Pitangui, em altitudes iguais ou superiores a 930 metros e margem direita (retângulo), notam-se orientações significativas voltadas a leste, sul e sudeste.

A segunda unidade de paisagem (Figura 8) apresenta maior heterogeneidade nas direções das encostas e em perímetros maiores distribuídas pela área, indicando ângulos voltados para sul, sudoeste e oeste. Salienta-se que estas áreas encontram-se em porções mais elevadas do terreno - acima de 1.000 metros - (círculo norte-noroeste). Em algumas porções menos elevadas da área - 1.000 metros aproximadamente - conforme mostra o retângulo, as direções estão voltadas para norte, noroeste e leste.

Figura 8 - Imagem representando aspecto e hidrografia-segunda unidade de paisagem
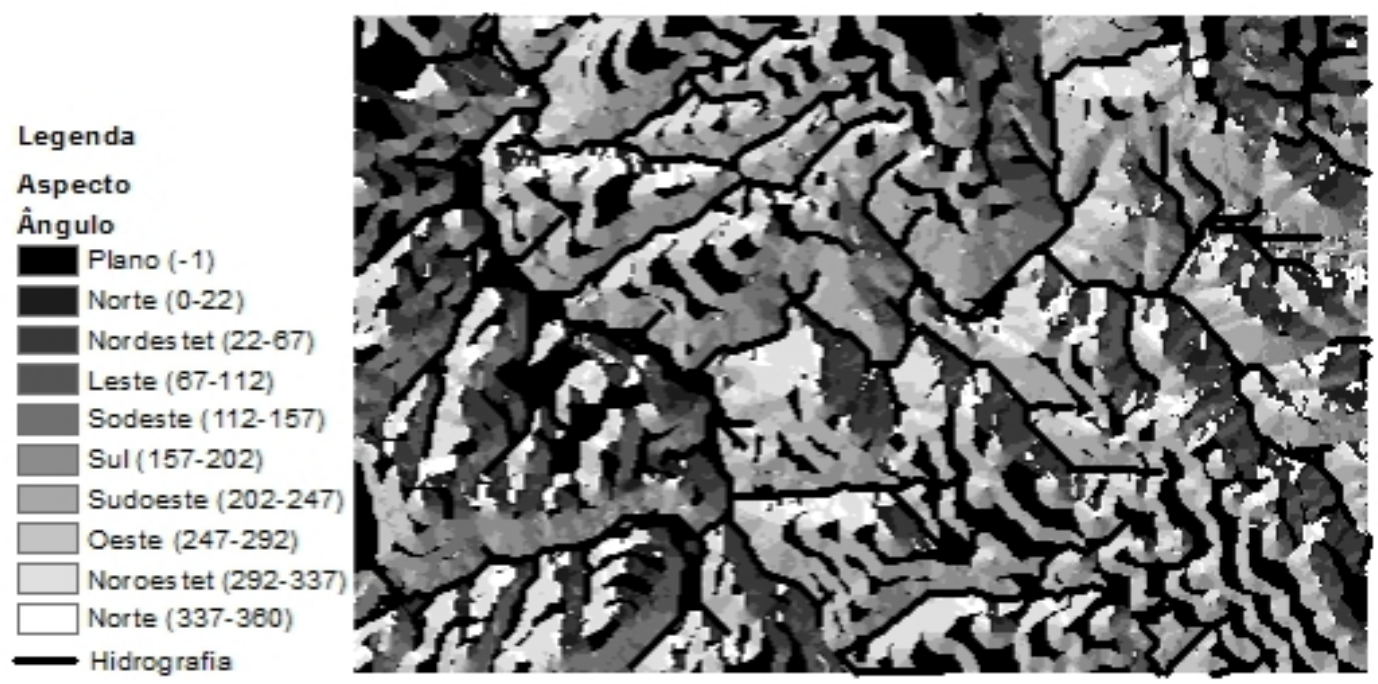

As variáveis altitude e declividade somadas ao aspecto das unidades, onde se nota uma ordenação ou homogeneização maior no padrão de inclinação, principalmente na primeira unidade (Figura 7), podem estar relacionadas à litologia local, uma vez que essa área apresenta-se basicamente sob o Complexo Granítico Cunhaporanga. Já a segunda unidade de paisagem (Figura 8) encontra-se inserida sob a Formação de Furnas, com presença de diques, falhas e fraturas, impulsionando os padrões heterogêneos de aspectos percebidos. Outro destaque para a segunda unidade refere-se a maiores perímetros de área com inclinação voltada para leste, de acordo com a tonalidade da Figura 8. Esta característica, cruzada com a topografia da área, pode denotar porções de maior uso e ocupação do solo, uma vez que recebe mais luz solar.

O entendimento da variável direção de escoamento (Figuras 9 e 10) ocorre ao analisar a sequência de pixels que estão alinhados, pela orientação das vertentes, determinando assim seu caminhamento de jusante a montante do fluxo. $O$ fluxo segue os perfis de vertente, transportando diferentes tipos de cargas, o que tem influência direta sobre o modelamento topográfico. 
De acordo com as características morfológicas presentes nas unidades de paisagem (Figuras 9 e 10), associadas às variáveis altimetria, declividade, aspecto e tipos de vertentes, notam-se heterogeneidades na distribuição do padrão de drenagem. A presença dos granitos na primeira unidade de paisagem (Figura 9) desencadeia drenagens de padrão paralelo ou subparalelo.

Figura 9 - Imagem representando direção de escoamento e hidrografia-primeira unidade de paisagem
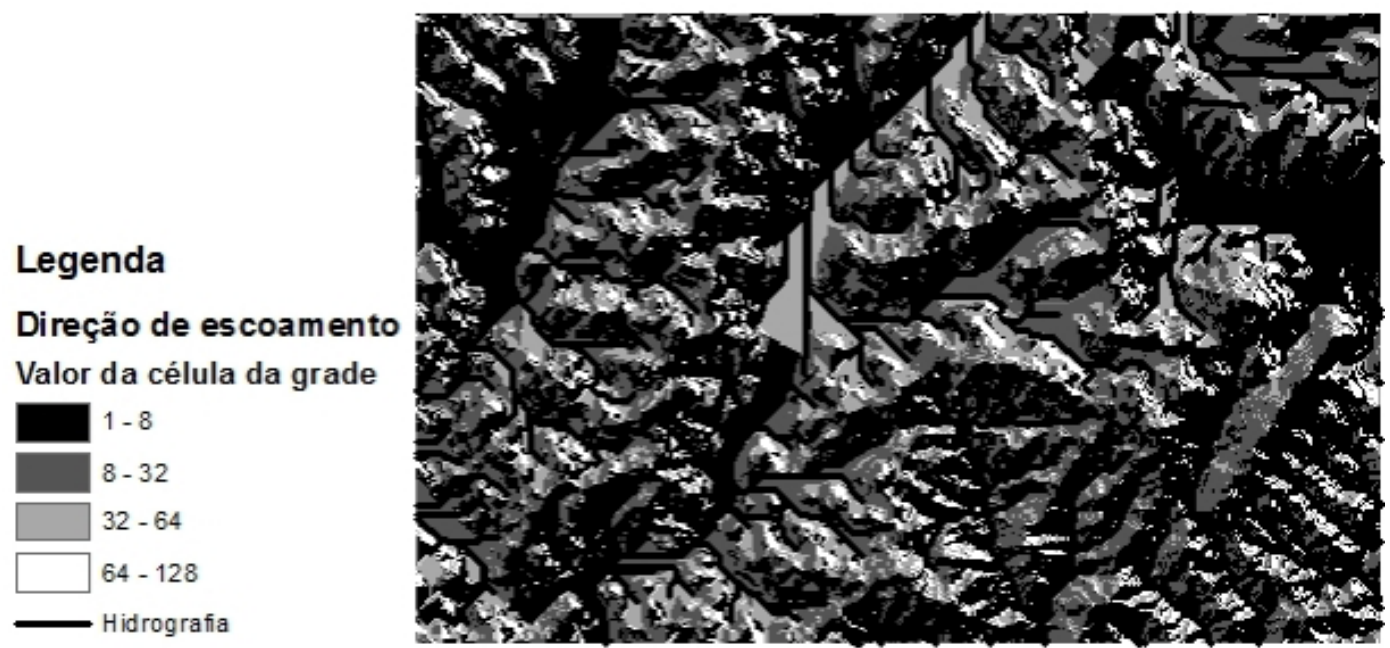

Em contrapartida, a diversidade geológica (Formação Furnas, Grupo Castro, falhas e fraturas) encontrada, principalmente na segunda unidade (Figura10), contribui para o desenvolvimento de drenagem com padrão dendrítico e controle estrutural.

Figura 10 - Imagem representando direção de escoamento e hidrografia-segunda unidade de paisagem

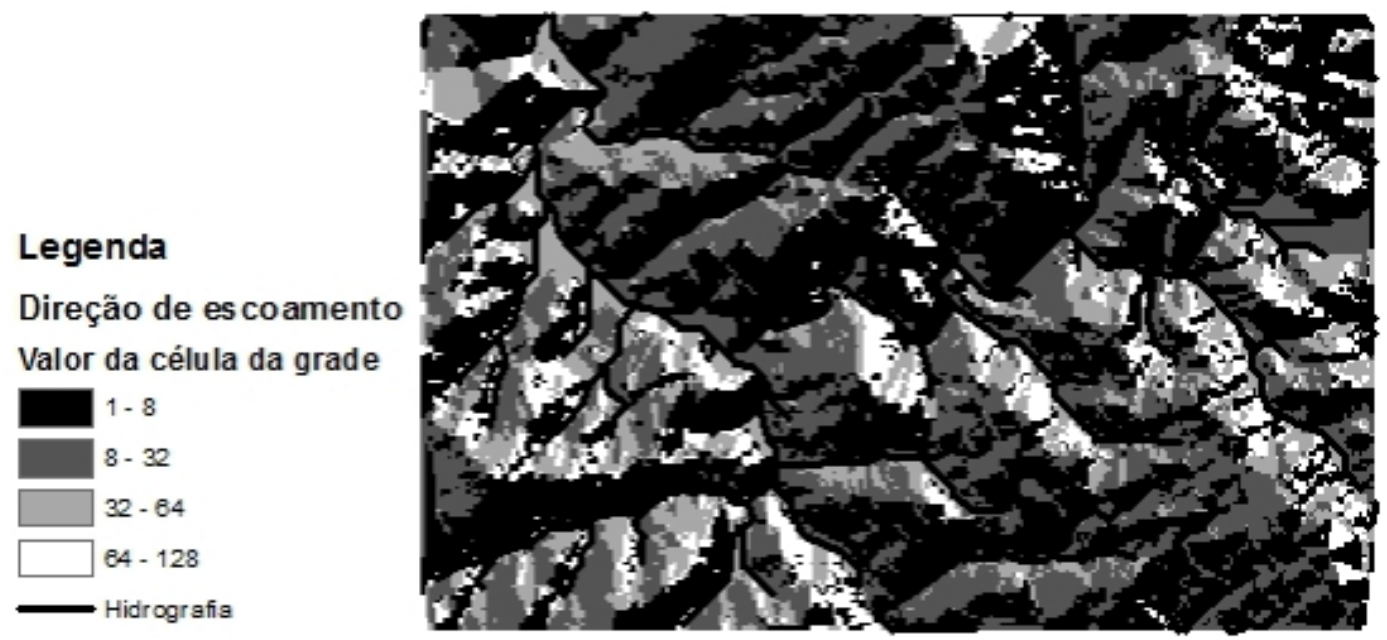

A rede hidrográfica é considerada um dos agentes mais influentes e ativos atuando na transformação e na alteração do relevo. Neste caso, visualmente nota-se em ambas as unidades uma densidade expressiva de afluentes (embora não realizado cálculo), principalmente do rio Pitangui. A orientação do escoamento segue um controle estrutural tridirecional, ou seja, a maioria das vertentes e escoamentos segue direções noroeste/ 
oeste/sudoeste. Atribuem-se estas particularidades à configuração morfológica e hidrográfica do Primeiro e do Segundo Planalto Paranaense, que, conforme mencionado anteriormente, possui escalonamento de leste para oeste e drenagem seguindo em direção ao rio Paranapanema, no oeste do estado.

Uma das características mais importantes associada ao processo de formação das bacias hidrográficas está ligada ao escoamento/drenagem que, nesse caso, não se trata apenas de hidrologia, mas da hidrografia, que é um fator geográfico. O perfil da bacia compreende áreas entre os seus divisores hidrográficos, que determinam a direção do fluxo que escoa para o canal principal. A proporção dessas áreas caracteriza a similaridade ou heterogeneidade geográfica e topográfica da bacia.

Por isso, na distribuição e orientação das sub-bacias das unidades em questão (Figuras 11 e 12), consideram-se, igualmente, as características relacionadas à morfologia e à hidrografia.

Figura 11 - Imagem representando sub-bacias e hidrografia-primeira unidade de paisagem

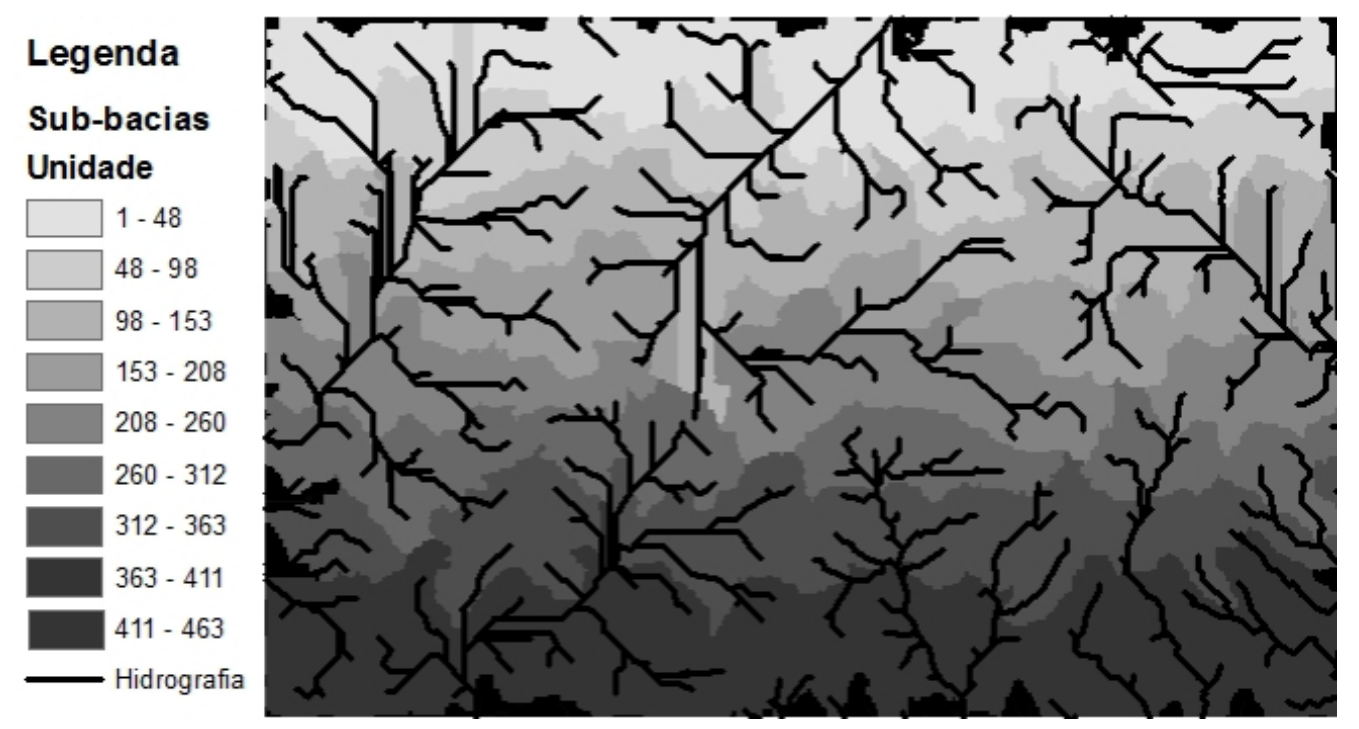

Figura 12 - Imagem representando sub-bacias e hidrografia-segunda unidade de paisagem

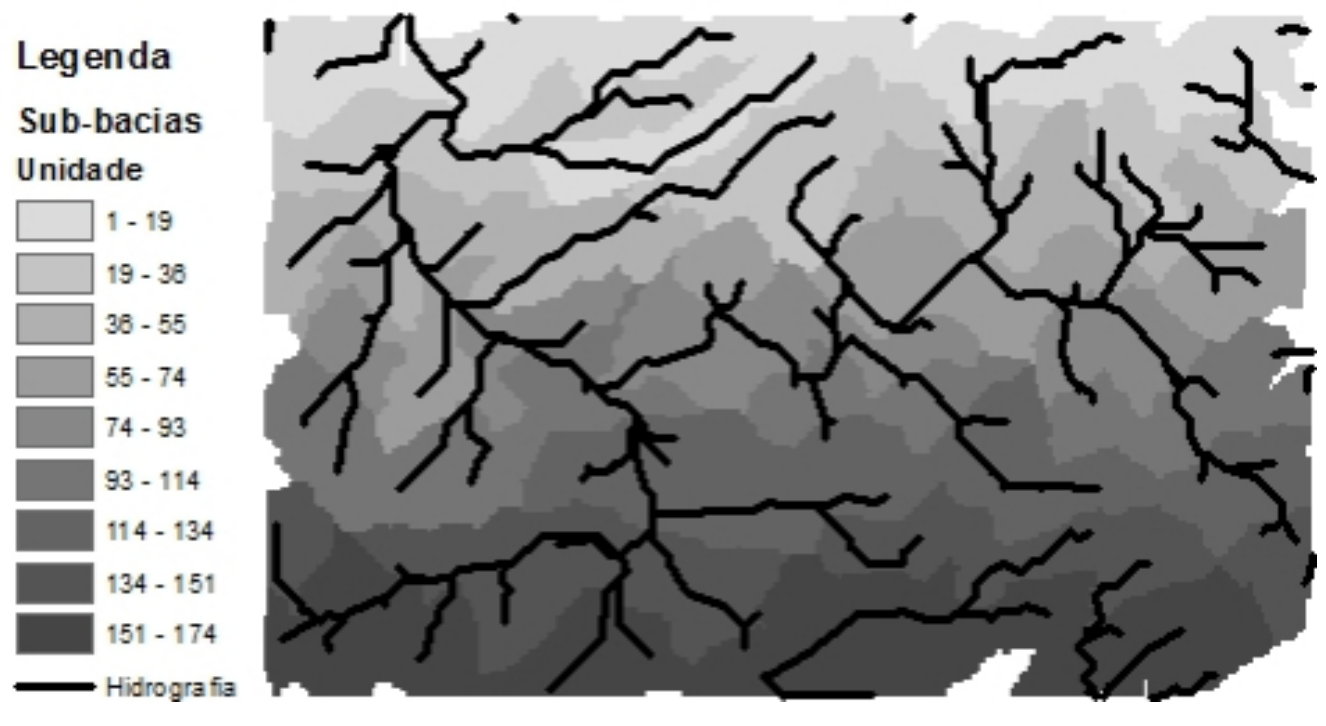


Nota-se que em ambas as unidades, nas porções onde há indícios de orientação, o padrão segue principalmente direções oeste/noroeste/sudoeste, como se pode observar nas setas a sudeste e noroeste da primeira unidade (Figura 11) e porções ao norte da segunda unidade de paisagem (Figura 12).

Estas características confirmam as direções do escoamento e dos divisores topográficos já analisados. O tamanho de cada sub-bacia está relacionado com o limiar escolhido no processamento (neste caso a limiar foi 500), e as formas predominantemente alongadas deve-se à associação com a geologia e geomorfologia locais.

Para a classificação digital MAXVER (Figuras 13 e 14) utilizaram-se as classes de acordo com o manual do IBGE (solo exposto, floresta, agricultura, corpo d'água, área urbana e sombra), comprovando mediante análise em campo.

Na primeira unidade de paisagem (Figura 13) identificou-se uma porção expressiva de "floresta", principalmente nas regiões norte-sudeste, leste-sudeste e centro-oeste. Estas porções são as que apresentam as maiores altitudes e declividades, justificando assim um menor aproveitamento. Nota-se quantidade expressiva da "agricultura", porém, em menor quantidade nas regiões supracitadas. Percebe-se nesta unidade parte da Represa Alagados (a oeste-noroeste), tendo como contribuintes o rio Pitangui e o rio Jotuba, que apresentam em suas zonas ripárias remanescentes da Floresta Ombrófila Mista, bem como de estepes.

Adotou-se a classe "sombra", uma vez que sua tonalidade, ao fazer-se a coleta das amostras, era confundida com os corpos hídricos, divergindo os resultados quando feitos testes de erros. Contudo, após sua inserção, o resultado da Matriz de Confusão gerou índice de $94 \%$ de acuracidade e o índice Kappa de 0,93, aferindo concordância da unidade de paisagem com a realidade.

Figura 13 - Imagem representando uso e ocupação do solo-primeira unidade de paisagem
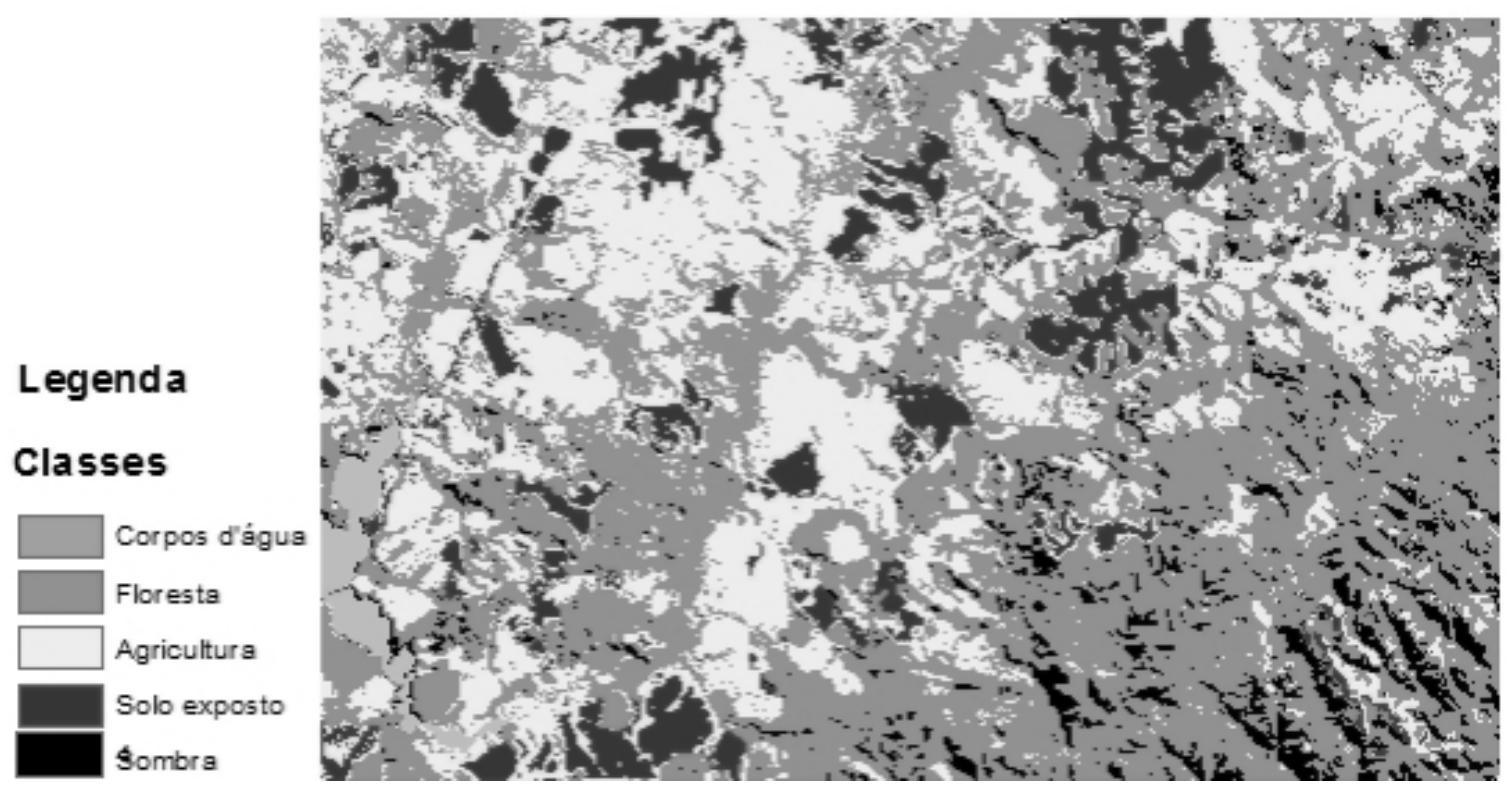
Na segunda unidade de paisagem (Figura 14) puderam ser comprovados os resultados realizados pela Matriz de Confusão, a qual mostrou um índice de acuracidade de $88 \%$, denotando que houve um erro de omissão, principalmente na classe caracterizada como "Urbana" (setas), que apresentou pixels similares aos da classe "solo exposto", alterando-a. O índice Kappa apontou uma acuracidade de 0,86, o qual indica que a imagem obteve concordância na classificação.

Figura 14 - Imagem representando uso e ocupação do solo-segunda unidade de paisagem

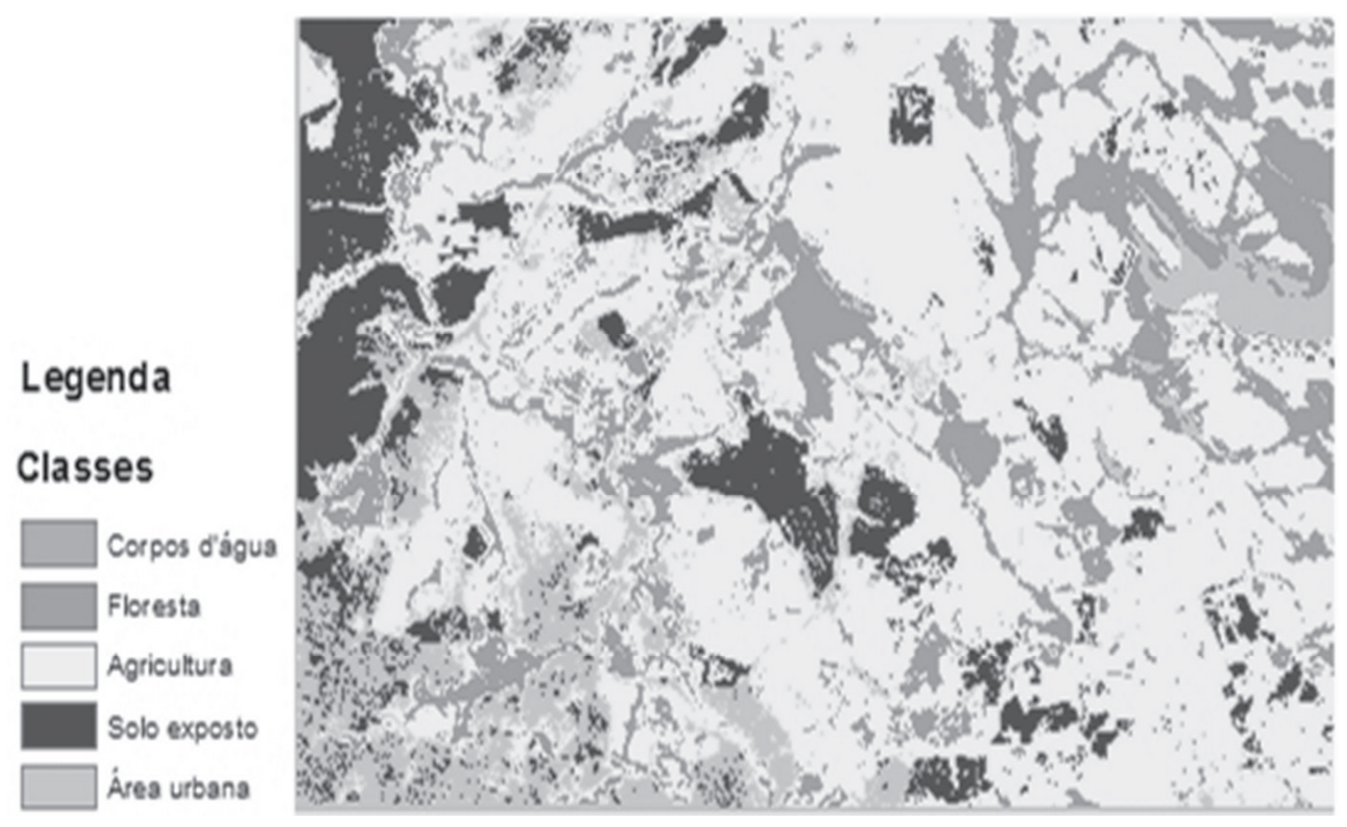

A análise mostrou que a primeira unidade de paisagem (Figura 13), conforme já mencionado, apresenta maior quantidade de vegetação, principalmente em regiões elevadas e com maior declividade (sul-sudeste, leste-sudeste), diferenciando-se da segunda unidade de paisagem (Figura 14), a qual denota usos mais intensos pela agricultura, inclusive nas regiões mais elevadas (norte, nordeste, sudeste) e pela porção urbana do município de Ponta Grossa (setas sudoeste). Percebe-se nesta área menor quantidade de vegetação, inclusive nas áreas ribeirinhas. Tais características podem influenciar, a médio prazo, mudanças físicas da paisagem ou até mesmo comprometer sua estrutura pelo uso e ocupação intensos.

\section{CONCLUSÕES}

As variáveis associadas à geomorfologia e à hidrografia são potencialmente úteis para a caracterização de unidades de paisagens, como neste estudo. A análise visual das imagens representando os elementos formadores das paisagens (MDT, declividade, direção de escoamento, sub-baciais/hidrografia e uso e ocupação do solo) permitiram a descrição e comparação das unidades, podendo-se compreender de forma integrada os espaços, ou seja, de acordo com as características físicas e de uso e ocupação. 
Neste sentido, mediante análise visual, identificaram-se características homogêneas nas duas unidades de paisagem atribuídas, sobretudo quanto ao relevo, comprovando-se que, quando este possui uma determinada altitude associada a declividades suave e suave ondulada, tem-se uso do solo intenso, seja ele agrícola ou urbano. Pôde-se, ainda, perceber usos antrópicos menos intensos em porções onde o relevo se apresenta como fator limitante, constado mediante as classes de declive.

Quanto à heterogeneidade das unidades de paisagem, o fator mais relevante encontrado está relacionado às drenagens, uma vez que os espaços onde se encontram as unidades de estudo possuem diferentes estruturas físicas, exibindo hidrografia de padrão paralelo e subparalelo na primeira unidade, e dendrítica com controle estrutural na segunda unidade de paisagem.

Considera-se a Represa Alagados, inserida entre as unidades de estudo, como fator relevante para esta análise, uma vez que exerce forte contribuição tanto para a caracterização física quanto de uso e ocupação, percebidos não somente nas unidades delimitadas, mas na área total da bacia hidrográfica. É importante salientar que a Represa está inserida sob o relevo de transição (ED), entre o Primeiro e o Segundo Planalto, porção esta caracterizada pela sua singularidade geomorfológica regional.

\section{REFERÊNCIAS}

BUREL, F; BAUDRY, Y.J. Ecologia del paisaje. Madrid: Ediciones Mundi Prensa, 2002, 353p.

BURROUGH, P. A. Principles of Geographical Information Systems for Land Resources Assessment. Clarendon Press. England: Oxford, 1986.

Principles of Geographical Information Systems for Land Resources Assessment Clarendon Press. England: Oxford, 1992.

CENTENO, J. A. S. Sensoriamento Remoto e Processamento de Imagens Digitais. Departamento de Geomática. Curitiba: UFPR, 2003, 210p.

Sensoriamento Remoto e Processamentos de Imagens digitais. Curitiba: Ed. Curso de Pós Graduação em Ciências Geodésicas, Universidade Federal do Paraná. 2004, 219p.

CRUZ, G. C. F. Alguns aspectos do clima dos Campos Gerais. In: MELO, M.S.; MORO, R.S.; GUIMARÃES, G.B. (Eds.). Patrimônio Natural dos Campos Gerais do Paraná. Ponta Grossa: Ed. UEPG, 2007. p. 59-72.

EMBRAPA/CNPS. Boletim de Pesquisa e Desenvolvimento. Rio de Janeiro, n. 9, 2002.

FORMAN, R.T.T. Land Mosaics. The ecology of landscapes and regions. Cambridge University Press, 1995, 632p.

FORMAN, R.; GODRON, M. Landscape Ecology. New York: John Wiley \& Sons, 1986, 620 p.

GEALH, A.M.; MELO, M.S.; MORO, R.S. (Orgs.). Pitangui, rio de contrastes: seus lugares, seus peixes, sua gente. Ponta Grossa: Ed. UEPG, 2010, 199p.

GONZALES, R.C.; WOODS, R.E. Digital Image Processing. Addison-Wesley Publishing Company, 2000. 630p.

JENSEN J. R. Remote Sensing of Environment: an Earth Resource Perspective. New Jersey: Prentice-Hall Series in Geographical Information, 2000, 544 p.

. Sensoriamento Remoto do Ambiente. Tradução de J. C. N. Epiphanio et al. São José dos Campos, SP: Parênteses, 2009, 672p. 
LANG, S.; BLASCHKE, T. Análise da paisagem com SIG. Tradução de Hermann Kux. São Paulo: Oficina de Textos, 2009, 424p.

MAACK, R. Geografia física do Estado do Paraná. Curitiba: Imprensa Oficial, 2002, 440p.

MARQUES FILHO, O.; VIEIRA NETO, H. Processamento Digital de Imagens. Rio de Janeiro: Brasport, 1999, 406p.

MELO, M. S. et al. Relevo e hidrografia dos Campos Gerais. In: MELO, M. S.; MORO, R. S.; GUIMARÃES, G. B. Patrimônio Natural dos Campos Gerais do Paraná. Ponta Grossa: Editora UEPG, 2007. p. 49-58.

MOLINA, P. H., El paisaje natural en la confluencia de los ríos Jarama y Manzanares (Madrid). Ería. Departament de Geografía de la Universidad de Oviedo.p. 105-123.Oviedo, 1992.

MOREIRA, M. A. Fundamentos do Sensoriamento e Metodologia de Aplicação. 3.ed. Viçosa: Ed. UFV, 2005, 320p.

NOVO, E. M. L. M. Sensoriamento Remoto. Princípios e aplicações. São Paulo: Edgard Blucher, 1989, 308p.

PRICHOA, C. E. Estudo em duas unidades de paisagem da bacia hidrográfica do rio Pitangui, PR, mediante estatística multivariada e análise orientada a objetos. Dissertação (Mestrado) Universidade Estadual de Ponta Grossa, Ponta Grossa, 2012, 141p.

RIBEIRO, S. R. A. Integração de Imagens Landsat TM e dados auxiliares para a delimitação automática de unidade fisionômicas (paisagem) e geológicas usando redes neurais artificiais. Tese (Doutorado) Universidade Federal do Paraná, Curitiba, 2003, 189p.

TAVARES, A. C.; VITTE, A. C. Erosão dos solos e assoreamento de represas: o caso de Monte Aprazível (SP). Geografia, Rio Claro, v. 18, n. 1, p.51-95, 1993.

TURNER, M.G.; GARDNER, R.H.; O'NEILL, R.V. Landscape Ecology. Theory and practice-pattern and process. New York: Springer, 2001.

VELOSO, H. P.; RANGEL FILHO, A. L.; LIMA, J. C. A. Classificação da Vegetação Brasileira, adaptada a um sistema universal. Rio de Janeiro: IBGE, 1991. 123p. Disponível em: http://biblioteca.ibge.gov.br/ visualizacao/monografias/GEBIS\%20-

\%20RJ/classificacaovegetal.pdf. Acesso em: 18 jan. 2012.

\section{AGRADECIMENTOS}

Este artigo é parte de uma Dissertação de Mestrado, por isso, os autores agradecem a Coordenação de Aperfeiçoamento de Pessoal de Nível Superior (CAPES) pelo subsídio financeiro durante o desenvolvimento da pesquisa.

Recebido em 08-03-2014

Aceito para publicação em 20-03-2014 